\title{
Distribution of Isolates of Sclerotium rolfsii Tolerant to Pentachloronitrobenzene in Texas Peanut Fields
}

M.-Y. Shim, J. L. Starr, and N. P. Keller, Department of Plant Pathology and Microbiology, Texas A\&M University, College Station 77843; K. E. Woodard, Texas Agricultural Experiment Station, Stephenville 76401; and T. A. Lee, Jr., Texas Agricultural Extension Service, Stephenville 76401

\begin{abstract}
Shim, M.-Y., Starr, J. L., Keller, N. P., Woodard, K. E., and Lee, T. A., Jr. 1998. Distribution of isolates of Sclerotium rolfsii tolerant to pentachloronitrobenzene in Texas peanut fields. Plant Dis. 82:103-106.

The tolerance to pentachloronitrobenzene (PCNB) of an isolate of Sclerotium rolfsii collected in 1985 was quantified, and a survey of tolerance to PCNB in 377 other isolates of the fungus collected from Texas peanut fields from 1990 through 1994 was conducted. The effective dose $(\mathrm{ED})_{50}$ of the previously collected PCNB-tolerant isolate was $11.07 \mu \mathrm{g} \mathrm{PCNB} / \mathrm{ml}$ and was more than 5-fold greater than the $\mathrm{ED}_{50}$ of PCNB-sensitive isolates. The distribution of tolerance to PCNB among all isolates was slightly skewed, with 18 of the 377 isolates identified as having greater $(P \leq 0.05)$ tolerance to PCNB than the standard sensitive isolate. No isolate of $S$. rolfsii collected during the period of 1990 to 1994 had as high an $\mathrm{ED}_{50}$ value as did the 1985 isolate, even among those isolates collected from the same field from which the 1985 isolate was collected. $\mathrm{ED}_{50}$ values of two PCNB-sensitive and five PCNB-tolerant isolates were unchanged after 15 generations on potato dextrose agar amended with $10 \mu \mathrm{g} \mathrm{PCNB} / \mathrm{ml}$ or on unamended media. The PCNB-tolerant isolate collected in 1985 was less aggressive than other isolates in greenhouse and microplot tests, but no correlation was observed between $\mathrm{ED}_{50}$ values and disease incidence in these tests for other PCNB-sensitive and tolerant isolates. These data suggest that even though high levels of tolerance to PCNB can be confirmed in some isolates of $S$. rolf$s i i$, this phenomenon is likely to remain a rare event.
\end{abstract}

Additional keywords: fungicide resistance, stem rot of peanut

Pentachloronitrobenzene (PCNB) has been used with moderate success for many years for the control of stem rot (southern blight) of peanut (Arachis hypogaea L.), incited by Sclerotium rolfsii Sacc. $(2,12)$. However, there are numerous reports of inconsistent control of stem rot with PCNB (2,4-7,10,11). Smith et al. (16), reported that PCNB provided less than satisfactory control of peanut stem rot in Texas, and suggested that tolerance to PCNB may be partially responsible. In Georgia, control of stem rot with PCNB has been erratic also (17).

Considerable variation among isolates of $S$. rolfsii with respect to their sensitivity to PCNB has been reported $(1,2,7)$. Mean value of PCNB concentration that caused $50 \%$ inhibition of growth $\left(\mathrm{ED}_{50}\right)$ was 2.86 $\mu \mathrm{g} / \mathrm{ml}$, with a minimum and maximum of 0.03 and $5.63 \mu \mathrm{g} / \mathrm{ml}$ among 112 S. rolfsii

Corresponding author: J. L. Starr

E-mail: starr@ppserver.tamu.edu

This research was partially funded by grants from the Texas Peanut Producers Board and the USDA Southern Region IPM program.

Accepted for publication 25 September 1997.

Publication no. D-1997-1125-01R

(C) 1998 The American Phytopathological Society isolates collected from peanut fields in Oklahoma; however, $74 \%$ of the isolates were within one standard deviation of the mean (7). The $\mathrm{ED}_{50}$ values of two isolates from peanut in Georgia were 5.89 and 1.84 $\mu \mathrm{g} / \mathrm{ml}(2)$.

In 1960, Georgopoulos developed a strain of $S$. rolfsii that was tolerant to PCNB (9). This isolate was obtained after repeated culturing on media containing 30 $\mu \mathrm{g} \mathrm{PCNB} / \mathrm{ml}$. The growth rate of this isolate was reduced on media not containing PCNB, and tolerance to PCNB was maintained after repeated transfers on fungicide-free media.

A PCNB-tolerant isolate of $S$. rolfsii was detected in a peanut field in Comanche County, Texas in 1985 (K. E. Woodard, unpublished data). New fungicides (e.g., flutolnil and tebuconazole) have been registered for control of stem rot on peanut recently, and reliance on PCNB is decreasing. PCNB, however, remains a tool for management of stem rot and will continue to be useful, especially should populations of $S$. rolfsii develop resistance to the newer fungicides. The objectives of this study were to quantify the tolerance to PCNB of the isolate collected in 1985, to determine the distribution of isolates of $S$. rolfsii with PCNB-tolerance in Texas peanut fields, to determine stability of the PCNB-tolerance and whether it is a readily inducible trait, and to determine if any correlation exists between tolerance to PCNB and aggressiveness of $S$. rolfsii. A preliminary report has been presented (15).

\section{MATERIALS AND METHODS}

Collection of isolates. Isolates of $S$. rolfsii from peanut were collected in three separate surveys. In the first survey, conducted in 1992 and 1993, five peanut fields in the reproductive stage of growth were intensively surveyed by collecting isolates from each disease focus of each field. Disease incidence was less than $1 \%$ in all fields, and all fields had a history of PCNB use. Three fields were in Comanche County, one field was in Erath County, and one field was in Eastland County. Diseased stems were collected from each disease focus and placed in a plastic bag. The original PCNB-tolerant isolate (isolate Sr4/26) collected in 1985 was from one of the fields in Comanche County that was intensively sampled in 1992 and 1993.

In the second survey, one field each from Comanche and Erath counties was systematically sampled before planting in June 1993. Approximately $300 \mathrm{~g}$ of soil were taken from the upper $10 \mathrm{~cm}$ of the soil profile at intersections of 6- by 6-m quadrants established in each field (14). Sclerotia were extracted from $200 \mathrm{~cm}^{3}$ samples of soil by elutriation (3) and were caught on $780-\mu \mathrm{m}$ pore size sieves (14). In the Comanche County field, 200 samples were collected, whereas 100 samples were collected from the Erath County field.

The third survey was an arbitrary collection of isolates of $S$. rolfsii from 33 widely separated peanut fields in eight Texas counties. These fields were sampled during reproductive stages of peanut growth during 1990, 1992, and 1994.

All sclerotia were germinated on $1.5 \%$ water agar at room temperature. A hyphal tip from each germinated sclerotium was transferred to potato dextrose agar (PDA) for further growth and production of sclerotia. Mature sclerotia of each isolate produced on PDA were air-dried and stored in sterile polypropylene tubes at room temperature. The mycelial compatibility group (MCG), an indication of genetic relatedness, of each isolate was determined in a separate study (13).

PCNB screening. Each isolate of $S$. rolfsii was screened to determine sensitivity to PCNB (Sigma Chemical Co., St. 
Louis). In initial experiments, radial hyphal growth of the PCNB-tolerant isolate, Sr4/26, collected in 1985 was compared to wild-type, sensitive isolate Sr1/1 on PDA in 100 - by $15-\mathrm{mm}$ diameter petri dishes amended with $0,1,10,50$, or $100 \mu \mathrm{g}$ $\mathrm{PCNB} / \mathrm{ml}$ (Fig. 1). To incorporate PCNB into PDA, the PCNB was first dissolved in $10 \mathrm{ml}$ xylene/liter medium. The amount of xylene used in this study did not affect mycelial growth of $S$. rolfsii $(P \leq 0.05$; data not presented). The relationship between mycelial growth and concentration of PCNB was determined by regression analysis, and $\mathrm{ED}_{50}$ values for isolates $\mathrm{Sr} 1 / 1$ and $\mathrm{Sr} 4 / 26$ were calculated from regression equations.

Subsequently, each isolate from the surveys was screened for sensitivity to $10 \mu \mathrm{g}$ $\mathrm{PCNB} / \mathrm{ml}$ PDA. Sclerotia of each isolate were placed on PDA and, after 3 to 4 days' growth, 5-mm-diameter agar plugs were cut from the advancing margin of the colony. The agar plug was then transferred to PDA and PCNB-amended PDA and incubated at $27^{\circ} \mathrm{C}$ in darkness. Radial colony growth was measured after $72 \mathrm{~h}$ from three replicated cultures of each isolate on each media, and percentage growth inhibition calculated.

Alteration of tolerance to PCNB. Seven isolates of $S$. rolfsii (PCNB-sensitive isolates $\mathrm{Sr} 1 / 1$ and $\mathrm{Sr} 5 / 56-2$, and PCNB-tolerant isolates $\mathrm{Sr} 4 / 26, \mathrm{Sr} 5 / 21$, Sr5/23-4, Sr5/42, and Sr5/44-2) were used to test whether tolerance can be increased by continuous exposure to PCNB, or lost in the absence of the fungicide.

Three sclerotia of each isolate were placed separately on PDA or PDA amended with $10 \mu \mathrm{g} \mathrm{PCNB} / \mathrm{ml}$ and were incubated at $27^{\circ} \mathrm{C}$ in darkness. There were three replications of each isolate on each

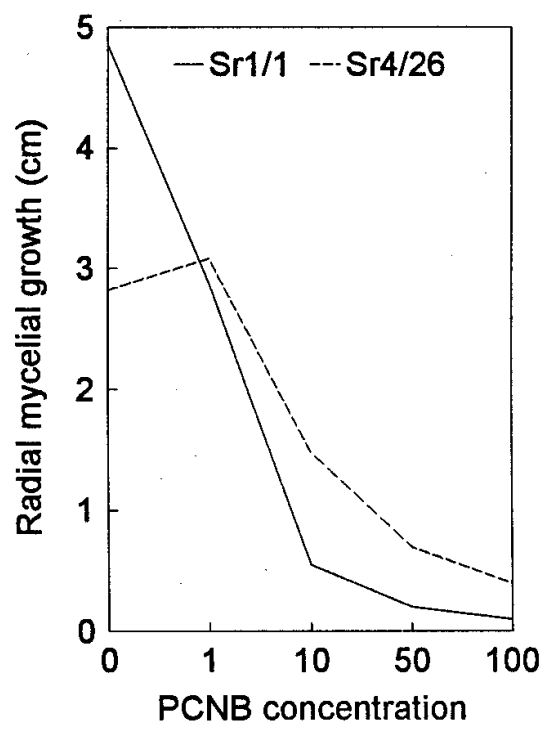

Fig. 1. Effect of pentachloronitrobenzene (PCNB) concentration on the mycelial growth of two isolates of Sclerotium rolfsii. Sr1/1 is a PCNB-sensitive isolate, whereas $\mathrm{Sr} 4 / 26$ is a PCNB-tolerant isolate collected from a peanut field in 1985 . media. After mycelial growth covered the dish, the three initial sclerotia were removed. After an additional 4 weeks, newly produced sclerotia were collected and stored in polypropylene tubes. Each subsequent generation was initiated from sclerotia produced by the preceding generation.

Aggressiveness of PCNB-tolerant and sensitive isolates. Eight isolates of $S$. rolfsii differing in sensitivity to PCNB were tested for aggressiveness in greenhouse and microplot experiments. Four PCNBsensitive isolates ( $\mathrm{Sr} 1 / 1, \mathrm{Sr} 5 / 26-3, \mathrm{Sr} 5 / 45$ 2, and $\mathrm{Sr} 5 / 59$ ) had $\mathrm{ED}_{50}$ values of 1.99 to $2.10 \mu \mathrm{g} P C N B / m l$, whereas the four PCNB-tolerant isolates ( $\mathrm{Sr} 4 / 26, \mathrm{Sr} 5 / 21$, Sr5/35-1, and Sr5/56-1) had $\mathrm{ED}_{50}$ values of 2.65 to $11.07 \mu \mathrm{g}$ PCNB/ml.

Inoculum consisted of infested oat grains prepared by placing four agar plugs (5-mm diameter) cut from the advancing margin of 3-day-old PDA cultures of each $S$. rolfsii isolate in separate $500-\mathrm{ml}$ flasks, each containing $50 \mathrm{~g}$ of autoclaved oat grains. The flasks were maintained at $27^{\circ} \mathrm{C}$ in darkness for 10 days. Infested oat grains were then spread on paper towels and airdried prior to use as inoculum.

For greenhouse tests, Florunner peanut seeds were germinated on wet paper towels for 3 days at room temperature. Two germinated seed were planted in each $15-\mathrm{cm}-$ diameter plastic pot containing a sand-peat (6:1, vol/vol) potting mix. Plants were maintained in a greenhouse with a temperature range of 24 to $34^{\circ} \mathrm{C}$. Each pot was infested with a single isolate of $S$. rolfsii 6 weeks after planting by placing $4 \mathrm{~g}$ of infested oat grains on the soil surface adjacent to peanut stems. Individual stems

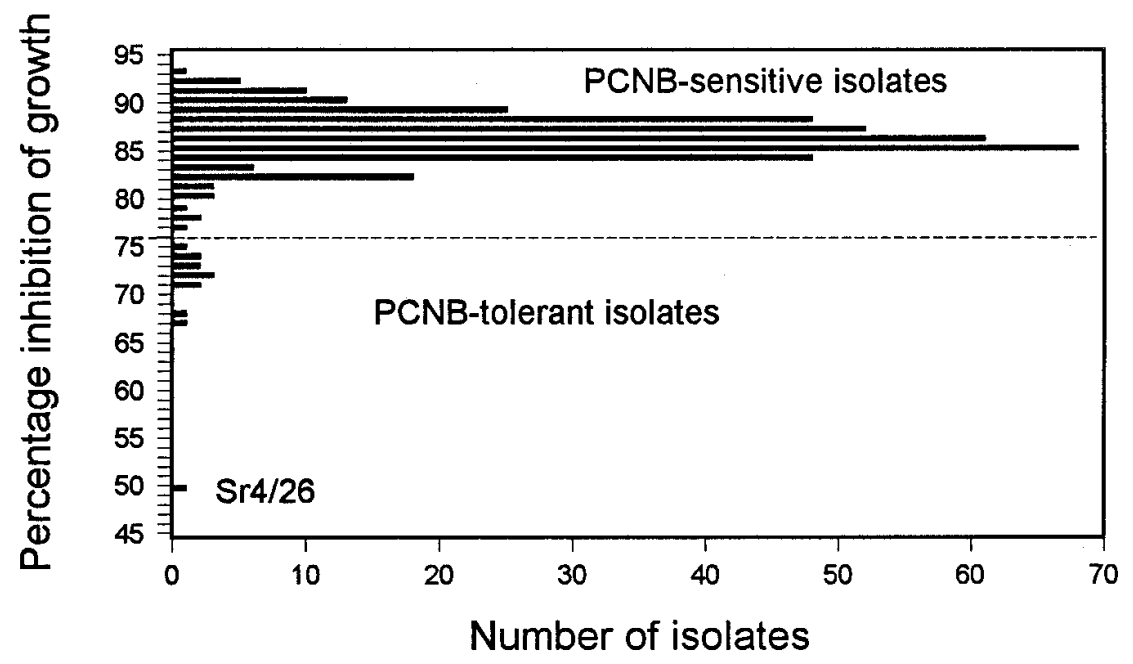

Fig. 2. Frequency distribution of sensitivity to $10 \mu \mathrm{g}$ pentachloronitrobenzene (PCNB)/ml potato dextrose agar among isolates of Sclerotium rolfsii collected from Texas peanut fields. The dashed lines separates PCNB-tolerant isolates from fungicide-sensitive isolates.

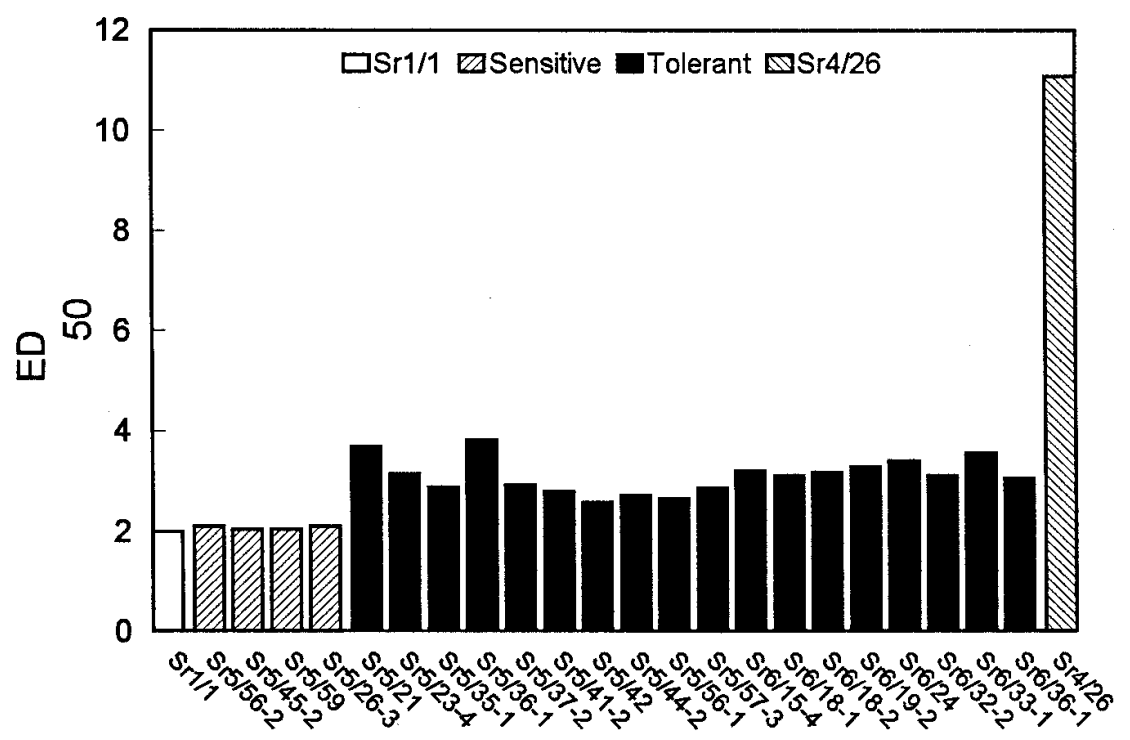

Fig. 3. Effective dose $(\mathrm{ED})_{50}$ values ( $\mu \mathrm{g}$ pentachloronitrobenzene $[\mathrm{PCNB}] / \mathrm{ml}$ ) of isolates sensitive and tolerant to PCNB. Sr1/1 is the standard sensitive isolate, whereas $\mathrm{Sr} 4 / 26$ is the PCNB-tolerant isolate from peanut in 1985 . 
developing symptoms of stem rot were counted at 10,14, and 21 days after infestation (DAI). Wilted stems with necrotic lesions and visible fungal growth on the stem and adjacent soil were considered diseased. The experiment was a completely randomized design and was conducted twice with eight replications per isolate.

For microplot tests, five Florunner peanut seeds were planted in each microplot (76 by $92 \mathrm{~cm}$ ) containing a sandy loam soil. Microplots were inoculated by placing $20 \mathrm{~g}$ of infested oat grains adjacent to peanut plants at 8 weeks after planting. Individual plants developing disease symptoms were counted at 14, 21, and 28 DAI. The experiment was a completely randomized design with five replications per isolate.

Data were subjected to analysis of variance using the SAS (SAS Institute, Cary, NC) general linear models procedure. The correlation of disease incidence with $\mathrm{ED}_{50}$ values for $S$. rolfsii isolates was tested by the SAS correlation procedure.

\section{RESULTS}

Fungal collection. Of 377 isolates of $S$. rolfsii collected, 287 were collected from diseased plants from the five intensively sampled peanut fields in 1992 and 1993. Nineteen isolates were recovered from 300 soil samples taken from the Comanche and Erath county fields during the systematic soil sample survey of 1993 . The remaining 71 isolates were obtained from arbitrarily selected peanut fields in Texas.

PCNB tolerance. Inhibition of radial mycelial growth of the PCNB-sensitive isolate $(\mathrm{Sr} 1 / 1)$ was greater than that of the PCNB-tolerant isolate $(\mathrm{Sr} 4 / 26 ; P \leq 0.05$; Fig. 1). Growth of $S r 4 / 26$ was slower than that of Sr1/1 in the absence of PCNB. These response curves were best described by linear regression models of percentage mycelial growth inhibition to $\log _{10}$ $(\mathrm{PCNB}+0.1)$, with $R^{2}=0.952$ for $\mathrm{Sr} 1 / 1$ and $R^{2}=0.862$ for $\mathrm{Sr} 4 / 26$. From these dose response curves, $\mathrm{ED}_{50}$ values were determined to be $1.99 \mu \mathrm{g} \mathrm{PCNB} / \mathrm{ml}$ for isolate $\mathrm{Sr} 1 / 1$ and $11.07 \mu \mathrm{g} / \mathrm{ml}$ for isolate $\mathrm{Sr} 4 / 26$.

The distribution of sensitivity to PCNB among the 377 isolates of $S$. rolfsii was slightly skewed (skewness $=-3.20$; Fig. 2). Based on this distribution pattern, isolates that were inhibited less than $80 \%$ by $10 \mu \mathrm{g} \mathrm{PCNB} / \mathrm{ml}$ were classified as tolerant to PCNB. Less than $5 \%$ of all isolates, including the original tolerant isolate $\mathrm{Sr} 4 / 26$ obtained in 1985 , were tolerant to PCNB. Ten isolates collected from the Comanche County field from which $\mathrm{Sr} 4 / 26$ originated and eight isolates collected from the Erath County field were tolerant to PCNB.

The 18 PCNB-tolerant isolates and four arbitrarily selected PCNB-sensitive isolates were examined for dose response to PCNB and compared with $\mathrm{Sr} 4 / 26$ as the standard tolerant isolate and $\mathrm{Sr} 1 / 1$ as the standard sensitive isolate. The mean $\mathrm{ED}_{50}$ value of the 18 new PCNB-tolerant isolates was $3.07 \mu \mathrm{g} \mathrm{PCNB} / \mathrm{ml}$, and all had $\mathrm{ED}_{50}$ values greater than that of the standard sensitive isolate $\operatorname{Sr} 1 / 1$ ( $P \leq 0.05$; Fig. 3$)$. However, no newly collected isolate tested in this study had an $\mathrm{ED}_{50}$ value equal to $\mathrm{Sr} 4 / 26$. The mean $\mathrm{ED}_{50}$ value for the four PCNB-sensitive isolates was $2.07 \mu \mathrm{g}$ $\mathrm{PCNB} / \mathrm{ml}$, and none were different from Sr1/1 $(P \geq 0.05)$.

Alteration of tolerance to PCNB. After 15 generations on PCNB-amended or nonamended PDA, there was no change $(P$ $\geq 0.05)$ in the $\mathrm{ED}_{50}$ values for any of the $S$. rolfsii isolates tested. No isolate had an $\mathrm{ED}_{50}$ value that differed by more than $3 \%$ from the original value.

Table 1. Effect of isolates of Sclerotium rolfsii that differed in sensitivity to pentachloronitrobenzene (PCNB) on percentage of diseased peanut stems in greenhouse experiments

\begin{tabular}{lccccl}
\hline & & & \multicolumn{3}{c}{ Disease incidence (\%) $^{\mathbf{x}}$} \\
\cline { 5 - 6 } Isolates & PCNB $^{\mathbf{y}}$ & ED $_{\mathbf{5 0}}{ }^{\mathbf{z}}$ & $\mathbf{1 0}$ DAI & 14 DAI & 21 DAI \\
\hline Sr1/1 & $\mathrm{S}$ & 1.99 & $56.7 \mathrm{bc}$ & $71.1 \mathrm{bc}$ & $93.0 \mathrm{ab}$ \\
Sr5/26-3 & $\mathrm{S}$ & 2.10 & $67.8 \mathrm{ab}$ & $82.9 \mathrm{ab}$ & $91.7 \mathrm{ab}$ \\
Sr5/45-2 & $\mathrm{S}$ & 2.04 & $63.5 \mathrm{ab}$ & $79.4 \mathrm{abc}$ & $81.2 \mathrm{~b}$ \\
Sr5/59 & $\mathrm{S}$ & 2.04 & $72.6 \mathrm{a}$ & $92.5 \mathrm{a}$ & $94.8 \mathrm{a}$ \\
Sr4/26 & $\mathrm{T}$ & 11.07 & $36.2 \mathrm{~d}$ & $36.2 \mathrm{~d}$ & $45.8 \mathrm{c}$ \\
Sr5/21 & $\mathrm{T}$ & 3.68 & $47.1 \mathrm{~cd}$ & $65.1 \mathrm{c}$ & $83.0 \mathrm{~b}$ \\
Sr5/35-1 & $\mathrm{T}$ & 2.87 & $68.4 \mathrm{ab}$ & $87.3 \mathrm{a}$ & $97.1 \mathrm{a}$ \\
Sr5/56-1 & $\mathrm{T}$ & 2.65 & $44.6 \mathrm{~cd}$ & $65.9 \mathrm{c}$ & $84.9 \mathrm{ab}$ \\
\hline
\end{tabular}

${ }^{\mathrm{x}} \mathrm{DAI}=$ Days after infestation. Means with the same letter in each column are not significantly different $(P \geq 0.05)$ according to Duncan's multiple range test.

y $\mathrm{PCNB}$ sensitivity; $\mathrm{S}=$ sensitive, $\mathrm{T}=$ tolerant.

${ }^{z}$ Effective dose for 50\% growth inhibition in $\mu \mathrm{g} \mathrm{PCNB} / \mathrm{ml}$.

Table 2. Correlation coefficients for the relationship between sensitivity to pentachloronitrobenzene $\left(\mathrm{PCNB} ; \mathrm{ED}_{50}\right.$ ) and aggressiveness (disease incidence) among isolates of Sclerotium rolfsii in greenhouse and microplot tests

\begin{tabular}{|c|c|c|c|}
\hline \multirow[b]{2}{*}{ Location } & \multirow[b]{2}{*}{ DAI $\mathbf{I}^{\mathbf{z}}$} & \multicolumn{2}{|c|}{ Correlation coefficient ${ }^{y}$} \\
\hline & & With Sr4/26 $(n=8)$ & Without $\operatorname{Sr} 4 / 26(n=7)$ \\
\hline \multirow{3}{*}{ Greenhouse } & 10 & $-0.711 *$ & $-0.562 \mathrm{~ns}$ \\
\hline & 14 & $-0.866 * *$ & $-0.480 \mathrm{~ns}$ \\
\hline & 21 & $-0.938 * *$ & $-0.289 \mathrm{~ns}$ \\
\hline \multirow[t]{3}{*}{ Microplot } & 14 & $-0.730 *$ & $-0.306 \mathrm{~ns}$ \\
\hline & 21 & $-0.899 *$ & $-0.247 \mathrm{~ns}$ \\
\hline & 28 & $-0.952 * *$ & $-0.480 \mathrm{~ns}$ \\
\hline
\end{tabular}

${ }^{y} \mathrm{Sr} 4 / 26$ is the PCNB-tolerant isolate of $S$. Rolfsii found in 1985 . *, ** indicates significance at $P=$ 0.05 and 0.01 , respectively, and ns indicates no significant correlation at $P=0.05$.

${ }^{\mathrm{z}} \mathrm{DAI}=$ days after inoculation.

Table 3. Effect of Sclerotium rolfsii isolates that differed in sensitivity to pentachloronitrobenzene (PCNB) on percentage of diseased peanut plants in microplot experiments

\begin{tabular}{lccccc}
\hline & & & \multicolumn{3}{c}{ Disease incidence (\%) $^{\mathbf{x}}$} \\
\cline { 5 - 6 } Isolates & PCNB $^{\mathbf{y}}$ & $\mathbf{E D}_{\mathbf{5 0}}^{\mathbf{z}}$ & $\mathbf{1 4}$ DAI & 21 DAI & 28 DAI \\
\hline Sr1/1 & $\mathrm{S}$ & 1.99 & $12 \mathrm{bc}$ & $28 \mathrm{a}$ & $48 \mathrm{a}$ \\
Sr5/26-3 & $\mathrm{S}$ & 2.10 & $44 \mathrm{a}$ & $48 \mathrm{a}$ & $60 \mathrm{a}$ \\
Sr5/45-2 & $\mathrm{S}$ & 2.04 & $40 \mathrm{a}$ & $52 \mathrm{a}$ & $52 \mathrm{a}$ \\
Sr5/59 & $\mathrm{S}$ & 2.04 & $36 \mathrm{ab}$ & $44 \mathrm{a}$ & $48 \mathrm{a}$ \\
Sr $4 / 26$ & $\mathrm{~T}$ & 11.07 & $0 \mathrm{c}$ & $0 \mathrm{~b}$ & $8 \mathrm{~b}$ \\
Sr5/21 & $\mathrm{T}$ & 3.68 & $24 \mathrm{abc}$ & $36 \mathrm{a}$ & $48 \mathrm{a}$ \\
Sr5/35-1 & $\mathrm{T}$ & 2.87 & $20 \mathrm{abc}$ & $44 \mathrm{a}$ & $44 \mathrm{a}$ \\
Sr5/56-1 & $\mathrm{T}$ & 2.65 & $36 \mathrm{ab}$ & $40 \mathrm{a}$ & $44 \mathrm{a}$ \\
\hline
\end{tabular}

${ }^{\mathrm{x}}$ DAI = days after infestation. Means with the same letter in each column are not significantly different $(P=0.05)$ according to Duncan's multiple range test.

y PCNB sensitivity; $\mathrm{S}=$ sensitive, $\mathrm{T}=$ tolerant.

${ }^{z}$ Effective dose for 50\% growth inhibition in $\mu \mathrm{g} \mathrm{PCNB} / \mathrm{ml}$. 
disease incidence was lower in microplots than in the greenhouse tests. The mean disease incidence for the PCNB-tolerant isolates was less than the mean disease incidence for the PCNB-sensitive isolates, and the lowest disease incidence $(P \leq 0.05)$ was incited by $\mathrm{Sr} 4 / 26$ at all assessment times (Table 3). A negative correlation between disease incidence and $\mathrm{ED}_{50}$ value was detected for all isolates tested (Table 2 ), but again these correlations were not significant $(P \geq 0.05)$ if isolate $\mathrm{Sr} 4 / 26$ was omitted from the analysis.

\section{DISCUSSION}

The $\mathrm{ED}_{50}$ value of the PCNB-tolerant isolate $\mathrm{Sr} 4 / 26$ originally collected in 1985 was more than five times greater than that of most PCNB-sensitive isolates. Only 18 additional isolates were identified as being tolerant to PCNB in these surveys of Texas peanut fields, and their tolerance was only about $50 \%$ greater than that of the sensitive isolates. Additionally, the PCNB tolerance of the newly collected tolerant isolates was not as great as that reported for isolates from Oklahoma and Georgia (2,7). Distribution of tolerance to PCNB was more skewed in this study than that reported from Oklahoma (7), but the range of tolerance was similar. No other isolate with a high level of tolerance to PCNB was identified, even though the field from which the original PCNB-tolerant isolate was collected was intensively sampled. Hence, PCNB-tolerance among isolates of $S$. rolfsii was not widespread in Texas peanut fields. The absence of a large number of isolates with high levels of tolerance to PCNB does not support the hypothesis that inconsistency of control of stem rot by PCNB is due to tolerance to the fungicide. Apparent inconsistency of control may be due to improper application technique, application rates, or variation in pathogen population density.

In previous reports, increased tolerance to PCNB has been induced in $S$. rolfsii by continuous exposure to the fungicide $(6,9)$. In this study, the PCNB-tolerance of several isolates of $S$. rolfsii was not altered, despite a range of initial tolerances to the fungicide among these isolates. That PCNB-tolerance has not been routinely observed among isolates of $S$. rolfsii, despite the widespread and long-term use the fungicide, suggests that isolates able to successfully adapt to the fungicide are rare. The antifungal activity of aromatic hydrocarbon fungicides, including PCNB, is proposed to be due to lipid peroxidation and subsequent effects on membrane integrity (8). This mode of action obviously is not easily overcome by most fungi.

In both the greenhouse and microplot experiments, there was an apparent correlation between tolerance to PCNB measured as $\mathrm{ED}_{50}$ values and aggressiveness of $S$. rolfsii. Yet these correlations were clearly due to the influence of isolate $\mathrm{Sr} 4 / 26$, and no such correlation was observed among isolates covering the range of fungicide tolerance detected in these surveys. The relatively slow growth rate of $\mathrm{Sr} 4 / 26$ on PDA, which was similar to previous reports of the effects of PCNB-tolerance on growth of $S$. rolfsii (9), may account for the lower aggressiveness of this isolate.

Nalim et al. (13) divided the 377 isolates from these surveys into $25 \mathrm{MCG}$. Sr4/26 belongs to MCG 11; no other isolate collected during this study belonged to MCG 11. As the perfect stage of $S$. rolfsii is rarely observed in nature, it is believed that exchange of genetic traits between isolates occurs mainly by hyphal fusion among members of the same MCG. Nalim et al. (13) suggested that the lack of other isolates with similar tolerance to PCNB as that of $\mathrm{Sr} 4 / 26$ may be due to the distinct MCG group of Sr4/26. This distinct MCG characteristic would prevent the PCNBtolerant trait from spreading to other isolates. The other PCNB-tolerant isolates, while significantly different from sensitive isolates, did not differ greatly with respect to PCNB-tolerance or growth rates and were distributed across four MCG. Each of these MCG also contained PCNB-sensitive isolates.

Because isolate $\mathrm{Sr} 4 / 26$ has limited pathogenic aggressiveness and a slow growth rate relative to the other isolates tested, it is likely that it was less fit than other isolates. The failure to detect any isolate with a similar level of PCNB-tolerance or in the same MCG in the field from which $\mathrm{Sr} 4 / 26$ was isolated suggests that this isolate did not survive at a detectable population density from 1985 until 1992.

\section{LITERATURE CITED}

1. Anilkumar, T. B., and Pandurange Gowda, K. T. 1984. Saprophytic activity of quintozene resistant isolate of Sclerotium rolfsii Sacc. in soil. J. Soil Biol. Ecol. 4:1-5.

2. Brenneman, T. B., Murphy, A. P., and Csinos, A. S. 1991. Activity of tebuconazole on Sclerotium rolfsii and Rhizoctonia solani, two soilborne pathogens of peanut. Plant Dis. 75:744-747.

3. Byrd, D. W, Barker, K. R., Nusbaum, C. J., Griffin, W. E., Small, R. H., and Stone, C. A. 1976. Two semi-automatic elutriators for extracting nematodes and some fungi from soil. J. Nematol. 8:212-216.

4. Csinos, A. S. 1984. Evaluation of insecticide chlorpyrifos for activity against southern stem rot of peanut. Peanut Sci. 11:98-102.

5. Csinos, A. S. 1985. Activity of tolclofosMethyl (Rizolex) on Sclerotium rolfsii and Rhizoctonia solani in peanut. Peanut Sci. 12:32-35.

6. Csinos, A. S. 1987. Control of southern stem rot and rhizoctonia limb rot of peanut with flutolanil. Peanut Sci. 14:55-58.

7. Damicone, J. P., and Jackson, K. E. 1994. Factors affecting chemical control of southern blight of peanut in Oklahoma. Plant Dis. 78:482-486.

8. Edlich, W., and Lyr, H. 1992. Target sites for fungicides with primary effects on lipid peroxidation. Pages 5368 in: Target Sites of Fungicide Action. W. Köller, ed. CRC Press, Boca Raton.

9. Georgopoulos, S. G. 1964. Chlorinated-nitrobenzene-tolerance in Sclerotium rolfsii. Ann. Inst. Phytopathol. Benaki. 6:156-159.

10. Hagan, A. K., Weeks, J. R., and Bowen, K. 1991. Effects of application timing and method on control of southern stem rot of peanut with foliar-applied fungicides. Peanut Sci. 18:47-50.

11. Hagan, A. K., Weeks, J. R., and Bowen, K. 1991. Effect of placement and rate of PCNB and PCNB + ethoprop on the control of southern stem rot of peanut. Peanut Sci. 18:94-97.

12. Harrison, A. L. 1961. Control of Sclerotium rolfsii with chemicals. Phytopathology 51:124-128.

13. Nalim, F. A., Starr, J. L., Woodard, K. E., Segner, S., and Keller, N. P. 1995. Mycelial compatibility groups in Texas peanut field populations of Sclerotium rolfsii. Phytopathology 85:1507-1512.

14. Punja, Z. K., Smith, V. L., Campbell, C. L., and Jenkins, S. F. 1985. Sampling and extraction procedures to estimate numbers, spatial pattern and temporal distribution of sclerotia of Sclerotium rolfsii in soil Plant Dis. 69:469-474.

15. Shim, M.-Y., Starr, J. L., and Woodard, K. 1995. Pathogenic aggressiveness of PCNBtolerant and sensitive isolates of Sclerotium rolfsii. (Abstr.) Phytopathology 85:511.

16. Smith, H. R., and Lee, T. A. Jr. 1986. Effect of tilt (propiconazole), terraclor (PCNB), and ridomil PC (metalaxyl $+\mathrm{PCNB}$ ) on Sclerotium rolfsii of peanuts. (Abstr.) Proc. Am. Peanut Res. Educ. Soc. 18:71.

17. Thompson, S. S. 1978. Control of southern stem rot of peanuts with PCNB plus fensulfothion. Peanut Sci. 5:49-52. 